University of Nebraska - Lincoln

DigitalCommons@University of Nebraska - Lincoln

USDA National Wildlife Research Center - Staff Publications
U.S. Department of Agriculture: Animal and Plant Health Inspection Service

$3-29-2003$

PREVALENCE OF ANTIBODIES TO NEOSPORA CANINUM, SARCOCYSTIS NEURONA, AND TOXOPLASMA GONDII IN WILD HORSES FROM CENTRAL WYOMING

\author{
J. P. Dubey \\ United States Department of Agriculture, Jitender.dubey@ars.usda.gov \\ S.M. Mitchell \\ Virginia-Maryland Regional College of Veterinary Medicine, Virginia Tech \\ J.K. Morrow \\ Equine Biodiagnostics, Inc.
}

J.C. Rhyan

National Wildlife Research Center, Animal Plant and Health Inspection Service, Veterinary Services, United States Department of Agriculture

L.M. Stewart

United States Department of Agriculture, Animal and Plant Health Inspection Service

See next page for additional authors

Follow this and additional works at: https://digitalcommons.unl.edu/icwdm_usdanwrc

Part of the Environmental Sciences Commons

Dubey, J. P.; Mitchell, S.M.; Morrow, J.K.; Rhyan, J.C.; Stewart, L.M.; Granstrom, D.E.; Romand, S.; Thulliez, P.; Saville, W.J.; and Lindsay, D.S., "PREVALENCE OF ANTIBODIES TO NEOSPORA CANINUM, SARCOCYSTIS NEURONA, AND TOXOPLASMA GONDII IN WILD HORSES FROM CENTRAL WYOMING" (2003). USDA National Wildlife Research Center - Staff Publications. 600.

https://digitalcommons.unl.edu/icwdm_usdanwrc/600

This Article is brought to you for free and open access by the U.S. Department of Agriculture: Animal and Plant Health Inspection Service at DigitalCommons@University of Nebraska - Lincoln. It has been accepted for inclusion in USDA National Wildlife Research Center - Staff Publications by an authorized administrator of DigitalCommons@University of Nebraska - Lincoln. 


\section{Authors}

J. P. Dubey, S.M. Mitchell, J.K. Morrow, J.C. Rhyan, L.M. Stewart, D.E. Granstrom, S. Romand, P. Thulliez, W.J. Saville, and D.S. Lindsay 


\title{
PREVALENCE OF ANTIBODIES TO NEOSPORA CANINUM, SARCOCYSTIS NEURONA, AND TOXOPLASMA GONDII IN WILD HORSES FROM CENTRAL WYOMING
}

\author{
J. P. Dubey, S. M. Mitchell ${ }^{\star}$ J. K. Morrow†, J. C. Rhyanł, L. M. Stewart§, D. E. Granstrom, S. Romand\|, P. Thulliez $\|$, \\ W. J. Saville\#, and D. S. Lindsay \\ Animal Parasitic Diseases Laboratory, Animal and Natural Resources Institute, Agricultural Research Service, United States Department of \\ Agriculture, Building 1001, Beltsville, Maryland 20705-2350. e-mail: jdubey@anri.barc.usda.gov
}

\begin{abstract}
Sarcocystis neurona, Neospora caninum, N. hughesi, and Toxoplasma gondii are 4 related coccidians considered to be associated with encephalomyelitis in horses. The source of infection for $N$. hughesi is unknown, whereas opossums, dogs, and cats are the definitive hosts for $S$. neurona, $N$. caninum, and $T$. gondii, respectively. Seroprevalence of these coccidians in 276 wild horses from central Wyoming outside the known range of the opossum (Didelphis virginiana) was determined. Antibodies to T. gondii were found only in 1 of 276 horses tested with the modified agglutination test using 1: 25, 1:50, and 1:500 dilutions. Antibodies to N. caninum were found in $86(31.1 \%)$ of the 276 horses tested with the Neospora agglutination test-the titers were $1: 25$ in 38 horses, 1:50 in 15, 1:100 in 9, 1:200 in 8, 1:400 in 4, 1:800 in 2, 1:1,600 in 2, $1: 3,200$ in 2 , and $1: 12,800$ in 1 . Antibodies to $S$. neurona were assessed with the serum immunoblot; of 276 horses tested, 18 had antibodies considered specific for $S$. neurona. Antibodies to $S$. neurona also were assessed with the $S$. neurona direct agglutination test (SAT). Thirty-nine of 265 horses tested had SAT antibodies-in titers of 1:50 in 26 horses and 1:100 in 13. The presence of $S$. neurona antibodies in horses in central Wyoming suggests that either there is cross-reactivity between $S$. neurona and some other infection or a definitive host other than opossum is the source of infection. In a retrospective study, $S$. neurona antibodies were not found by immunoblot in the sera of 243 horses from western Canada outside the range of $D$. virginiana.
\end{abstract}

Sarcocystis neurona, Neospora caninum, N. hughesi, and Toxoplasma gondii are related coccidians that are reported to cause encephalitis in horses. Of these 4 parasites, $S$. neurona is the most frequent cause of equine protozoal myeloencephalitis (EPM) in horses in the United States (Dubey et al., 1991; Dubey, Lindsay et al., 2001). The opossum (Didelphis virginiana) is the only known definitive host for $S$. neurona in the United States, and the distribution of EPM coincides with the geographic range of $D$. virginiana. Horses become infected by ingesting $S$. neurona oocysts or sporocysts excreted in feces of the opossum (Fenger et al., 1997; Dubey and Lindsay, 1998). More than $30 \%$ of horses tested in the United States were found to have antibodies to $S$. neurona by using immunoblot tests (IBTs) (Bentz et al., 1997; Blythe et al., 1997; Saville et al., 1997; Tillotson et al., 1999; Rossano et al., 2001; Daft et al., 2002).

Antibodies to $N$. caninum or $N$. hughesi or both were found in $23.3 \%$ of 296 horses from 2 meat packing plants in Nebraska and Texas (Dubey, Romand et al., 1999), in $11.5 \%$ of 536 horses in Alabama (Cheadle et al., 1999), in $11 \%$ of 208 horses from Missouri (Vardeleon et al., 2001), and in 23\% of 99 horses

Received 10 December 2002; revised 19 March 2003; accepted 31 March 2003.

* Center for Molecular Medicine and Infectious Disease, Department of Biomedical Sciences and Pathobiology, Virginia-Maryland Regional College of Veterinary Medicine, Virginia Tech, 1410 Prices Fork Road, Blacksburg, Virginia 44061-1092.

$\dagger$ Equine Biodiagnostics, Inc., 1501 Bull Lea Road, Suite 104, Lexington, Kentucky 40511.

$\ddagger$ National Wildlife Research Center, Animal Plant and Health Inspection Service, Veterinary Services, United States Department of Agriculture, 4101 La Porte Avenue, Fort Collins, Colorado 80521.

$\S$ United States Department of Agriculture, Animal and Plant Health Inspection Service, Veterinary Services Wyoming Area, 5353 Yellow Stone Park, Cheyenne, Wyoming 82009.

|| Laboratoire de la Toxoplasmose, Institut de Púericulture, 26 Boulevard Brune, F-75014 Paris, France.

\# Department of Veterinary Preventive Medicine, College of Veterinary Medicine, The Ohio State University, 1900 Coffey Road, Columbus, Ohio 43210-1092. from France (Pitel et al., 2001). Clinical neosporosis has been reported in a few horses only (Dubey and Porterfield, 1990; Daft et al., 1996; Gray et al., 1996; Lindsay et al., 1996; Marsh et al., 1996; Hamir et al., 1998; Cheadle et al., 1999; Pronost et al., 1999). The domestic dog (Canis familiaris) is the only known definitive host for N. caninum (McAllister et al., 1998); the definitive host for $N$. hughesi is unknown. Although Neospora spp. can be transmitted congenitally in horses (Dubey and Porterfield, 1990; Pronost et al., 1999), congenital equine neosporosis is considered a rare occurrence.

Before the discovery of $S$. neurona and $N$. caninum, clinical cases of EPM in horses were misdiagnosed as toxoplasmosis (reviewed in Dubey and Beattie, 1988; Dubey, Kerber et al., 1999). Compared with $S$. neurona and $N$. caninum, the seroprevalence of $T$. gondii in horses is low, and there is no proven case of clinical toxoplasmosis in horses. Antibodies to T. gondii were found in $6.9 \%$ of the 1,000 horses from the United States (Dubey, Thulliez et al., 1999). Felids are the definitive hosts for T. gondii (Dubey and Beattie, 1988).

The objective of the present study was to determine the seroprevalence of $S$. neurona, $N$. caninum, and T. gondii in wild horses from central Wyoming, outside the known geographic range of the opossum.

\section{MATERIALS AND METHODS}

\section{Wild horses from Wyoming}

Serum samples were obtained from 276 wild horses stationed at Honor Farms, near Riverton in central Wyoming (latitude $43^{\circ} 01^{\prime} 30^{\prime \prime} \mathrm{N}$, longitude $108^{\circ} 22^{\prime} 30^{\prime \prime} \mathrm{N}$ ). These horses were caught in the wild and kept on this farm before private adoption. The average stay of horses on this farm was no more than 4 mo. While on the farm, horses were fed alfalfa hay and occasionally grain grown on the farm. Opossums have not been observed in this area or in the areas from which the horses were captured. Data regarding approximate age and sex were available for most horses. One hundred and thirty-seven females and 139 males were included.

\section{Serologic testing}

Blood samples were obtained from a jugular vein, and serum samples were sent to the Animal Parasitic Diseases Laboratory (APDL), United 
TABle I. Antibodies to Neospora caninum in Wyoming horses of different ages.

\begin{tabular}{|c|c|c|c|c|c|c|c|}
\hline \multirow[b]{2}{*}{ Age $(y r)$} & \multirow{2}{*}{$\begin{array}{l}\text { No. of } \\
\text { horses }\end{array}$} & \multicolumn{5}{|c|}{ No. of horses with NAT titers of } & \multirow{2}{*}{$\begin{array}{c}\text { Total } \\
\text { positive }\end{array}$} \\
\hline & & 25 & 50 & 100 & 200 & $\geq 400$ & \\
\hline$<1$ & 29 & 4 & & 2 & 2 & & 8 \\
\hline 1 & 21 & 3 & & & & 2 & 5 \\
\hline 2 & 49 & 6 & 4 & 2 & & 3 & 15 \\
\hline 3 & 37 & 7 & 1 & 2 & & & 10 \\
\hline 4 & 28 & 6 & 3 & & & 1 & 10 \\
\hline 5 & 9 & 2 & 1 & & & 1 & 4 \\
\hline 6 & 13 & 2 & & 1 & 2 & & 5 \\
\hline 7 & 6 & & & & & & 0 \\
\hline 8 & 2 & 1 & & & & & 1 \\
\hline 9 & 7 & & & 2 & 1 & & 3 \\
\hline 10 & 6 & & 1 & & 1 & 1 & 3 \\
\hline 11 & 2 & & & & & & 0 \\
\hline 12 & 12 & 2 & 2 & & & 2 & 6 \\
\hline 13 & 8 & 1 & & & & 2 & 3 \\
\hline 14 & 13 & 1 & & & & 2 & 3 \\
\hline 15 & 7 & & & & 1 & 1 & 2 \\
\hline 16 & 3 & & & & & & 0 \\
\hline 18 & 2 & & & & & & 0 \\
\hline 20 & 6 & & & & 1 & & 1 \\
\hline 22 & 3 & & 1 & & & 1 & 2 \\
\hline 25 & 1 & & & & & & 0 \\
\hline Unknown & 12 & 3 & 2 & & & & 5 \\
\hline Total & 276 & 38 & 15 & 9 & 8 & 16 & 86 \\
\hline
\end{tabular}

States Department of Agriculture, Beltsville, Maryland, for serologic testing.

Antibodies to $T$. gondii and $N$. caninum were determined at APDL using direct agglutination tests. For $T$. gondii, sera were diluted 1:25, 1:50, and 1:500 and tested with the modified $T$. gondii agglutination test (MAT), according to a previously published protocol (Dubey and Desmonts, 1987). For $N$. caninum, sera were initially screened at 1:25, 1:50, and 1:500 dilutions using Neospora agglutination test (NAT), as described by Romand et al. (1998). Seropositive samples were titrated 2-fold, starting at 1:100 dilution.

Antibodies to $S$. neurona were determined by immunoblots as described (Granstrom et al., 1993; Dubey, Lindsay et al., 2001) and by $S$. neurona direct agglutination test (SAT) as described by Lindsay and Dubey (2001). The SAT was performed at the Center for Molecular Medicine and Infectious Diseases, Virginia Tech, Blacksburg, Virginia. The immunoblots were performed at Equine Biodiagnostics Inc. (EBI), Lexington, Kentucky. Antibodies (immunoglobulin G, $\operatorname{IgG}$ ) to S. neurona were essentially detected by immunoblot as described previously (Granstrom et al., 1993). Essentially, lysates of merozoites were subjected to electrophoresis through denaturing gradient polyacrylamide gels (sodium dodecyl sulfate, $10-20 \%$ polyacrylamide gel electrophoresis). After electrophoresis, separated proteins were electrically transferred to nitrocellulose paper by standard methods. Equine sera were incubated with the blot individually, and anti-S. neurona antibodies were detected using biotinylated anti-equine $\operatorname{IgG}$ followed by streptavidin-peroxidase conjugate and aminoethyl carbazole peroxide chromagen substrate.

\section{Domestic horses from western Canada}

During the course of studies on pathogenesis of $S$. neurona infection in horses (Saville et al., 2001; Sofaly et al., 2002), 243 horses from the Saskatchewan and Manitoba area, Canada, were screened for S. neurona antibodies to obtain negative horses for the experiments. Horses were obtained from these areas because they are outside the range of $D$.
TABLE II. Data on 18 horses with confirmed antibodies to Sarcocystis neurona detected by immunoblot.

\begin{tabular}{rrrrr}
\hline & & \multicolumn{3}{c}{ Concurrent antibody titers by } \\
\cline { 3 - 5 } Horse no. & Age & NAT & SAT & MAT \\
\hline 61 & 1 & $<25$ & $<50$ & $<25$ \\
36 & 2 & $<25$ & $<50$ & $<25$ \\
22 & 2 & $<25$ & 100 & $<25$ \\
94 & 2 & $<25$ & $<50$ & $<25$ \\
11 & 4 & $<25$ & $<50$ & $<25$ \\
22 & 4 & 25 & 100 & $<25$ \\
46 & 4 & 50 & $<50$ & $<25$ \\
21 & 5 & 25 & $<50$ & $<25$ \\
11 & 6 & $<25$ & 50 & $<25$ \\
5 & 10 & $<25$ & $<50$ & $<25$ \\
104 & 10 & 50 & 50 & $<25$ \\
54 & 13 & $<25$ & 50 & $<25$ \\
32 & 14 & $<25$ & $<50$ & $<25$ \\
59 & 15 & 800 & $<50$ & $<25$ \\
37 & 18 & $<25$ & $<50$ & $<25$ \\
64 & 20 & $<25$ & 50 & $<25$ \\
17 & Unknown & 25 & 100 & $<25$ \\
10 & Unknown & $<25$ & $<50$ & $<25$ \\
\hline
\end{tabular}

$*$ NAT $=$ Neospora agglutination test, SAT $=$ Sarcocystis neurona agglutination test, MAT $=$ Toxoplasma gondii modified agglutination test.

virgiana. Results of immunoblots performed on these horses at EBI are included in the present article.

\section{RESULTS}

\section{Wyoming horses}

Antibodies to $N$. caninum were found in $86(31.1 \%)$ of the 276 horses of all ages (Table I). Prevalences in females were similar to those in males. High antibody titers $(\geq 1: 400)$ were found in $18.6 \%$ of 86 seropositive horses; the highest titer was 1:12,800. Antibodies to T. gondii (MAT) were found in 1 horse, and the titer was only 1:25.

Antibodies to $S$. neurona were found by immunoblots in 18 of the 276 horses (Table II). By using the SAT, antibodies were found in 39 horses - in titers of 1:50 in 26 horses and 1:100 in 13. None of the 18 horses positive by immunoblot was positive by MAT; 6 were positive by NAT, and 7 were positive by SAT. Additionally, 15 horses exhibited equivocal (reported as weak) reactivity by immunoblot analysis. An illustration of the diversity of the immunoblot patterns is shown in a composite immunoblot (Fig. 1).

\section{Canadian horses}

Among the 243 horses from western Canada, immunoblot analyses were negative for 219 horses $(90.1 \%)$, weakly positive for $20(8.2 \%)$, and confirmed positive for 4 . It was later found that the 4 horses confirmed seropositive were raised in the United States.

\section{DISCUSSION}

Clinical $N$. caninum and $N$. hughesi infections have been reported in horses in the United States and France. The distinction between these 2 parasites is based essentially on molecular 
characteristics. The presence of shared antigens was demonstrated by the cross-reactivity in the NAT as well as in the indirect fluorescent antibody test (Marsh et al., 1996, 1998; Dubey, Liddell et al., 2001). Therefore, it is not possible to say whether the antibodies in $31 \%$ of wild horses from Wyoming were due to 1 or both parasites. These data indicate that the definitive host involved in the life cycle of equine Neospora spp. infections is present in central Wyoming. The $31 \% \mathrm{Neo}$ spora spp. seropositivity in horses of the present study is the highest reported to date. Previously, $23 \%$ of horses from the United States (Dubey, Thulliez et al., 1999) and France (Pitel et al., 2001) were reported to have $N$. caninum antibodies in the NAT. Whether the horses aquired Neospora spp. infections at the farm or in the wild is not known.

The NAT titer that should be considered specific for Neospora spp. infections has not been determined. Therefore, all titers are presented in the present study. The almost total absence of detectable T. gondii antibodies in horses with Neospora antibodies demonstrates the specificity of the NAT and MAT, confirming earlier findings in experimentally infected animals (Romand et al., 1998). Gupta et al. (2002) reported an indirect fluorescent antibody titer of 1:100 in a horse naturally infected with $N$. hughesi; they considered this finding to be the result of the cross-reactivity between these 2 organisms, but there is a possibility that the horse may have been exposed to both parasites.

The antemortem diagnosis of EPM remains a problem. The IBT was developed to detect the presence of $S$. neurona-specific antibodies in serum and cerebrospinal fluid (CSF). Although this test is not perfect, it is the best test available at present for the diagnosis of $S$. neurona. The IBT is highly specific if one considers weak positives as negatives, as supported by data obtained from Daft et al. (2002) and the present study with the horses from western Canada. Immunoblots from horses exposed to $S$. falcatula infections (Cutler et al., 1999) support the data on specificity of the IBT.

The lack of any apparent correlation between SAT and immunoblot in horses in the present study may be due to these tests measuring different antibodies. The SAT has not been evaluated for the diagnosis of EPM in experimentally infected horses or for use in clinical specimens.

Finding antibodies to $S$. neurona by immunoblot analysis in at least 18 horses native to Wyoming is unexpected and unexplained. Opossums are not known to occur in central Wyoming, and there has not been any confirmed case of EPM from horses native to Wyoming. Cross-reactivity with $N$. caninum was unlikely because 9 horses positive by $S$. neurona immunoblot had no detectable $N$. caninum antibody. Pitel et al. (2002) also reported $S$. neurona antibodies in horses native to France, although opossums do not occur in Europe.

As stated earlier, the IBT was developed by Granstrom et al. (1993) to detect $S$. neurona-specific antibodies in the serum and CSF of horses from the Western Hemisphere. This IBT is not known to cross-react with any related protozoan in limited investigations. Because it has not been possible to reliably induce verifiable EPM in horses, the only gold standard to evaluate the test is the verification of the parasite by postmortem immunohistochemical examination of the horses. Because it is not possible to rule out the absence of $S$. neurona by histologic examination of only a small amount

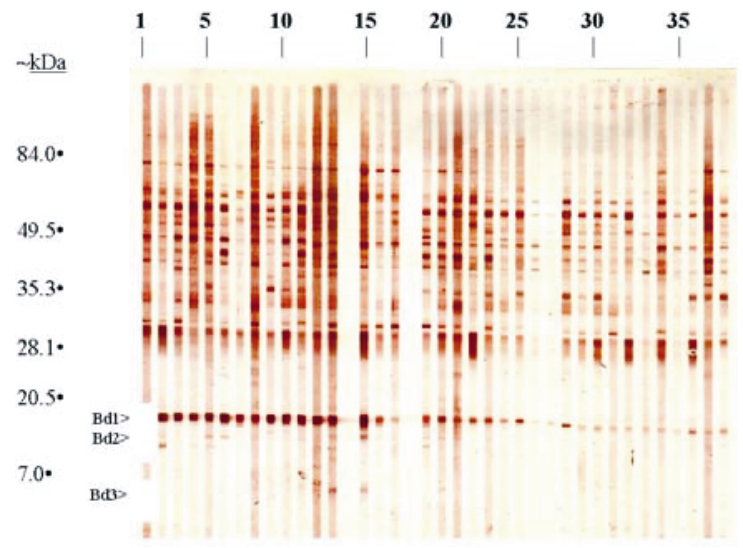

FIGURE 1. An immunoblot containing sera from a representative selection of the 276 study horses is shown. They were chosen on the basis of their immunoblot banding patterns and reactivities in the SAT assay. The Sarcocystis neurona-specific bands are designated by the numbered arrows to the left of the first lane, and their approximate molecular weights are based on the migration of standards of known molecular weight (far left). Band $1=14.5 \mathrm{kDa}$, band $2=12 \mathrm{kDa}$, and band $3=$ $<7 \mathrm{kDa}$. Lanes 15, 16, and 17 contain positive, diluted positive (for assessing lower detection limit), and negative sera, respectively. Lanes 14 and 18 are blank. Lanes $1-13$ contain sera that tested positive by IBT. The sera in lanes 1,8 , and 11 also had SAT titers of 1:50, 1:100, and 1:100, respectively. Lanes 19-23 contain sera with equivocal IBT reactivity. Of these, the serum in lane 20 also had a SAT titer of 1:50. Lanes 24-38 contain sera that tested negative by IBT. The sera in lanes $24,25,27,28,29,30,31$, and 37 had SAT titers of 1:100, 1:50, 1:100, $1: 100,1: 100,1: 100,1: 50$, and $1: 100$, respectively. Of the 33 sera shown in this immunoblot, 15 also had titers in the Neospora agglutination test, ranging from $1: 25$ (lanes $8,10,12,23,31,36$, and 37 ) to $1: 800$ (lanes 5 and 30).

of central nervous system tissue (in grams), only a positive identification is meaningful. Recently, Daft et al. (2002) critically evaluated the performance of IBT in horses with neurologic diseases. They found that IBT was strongly positive in all 12 horses with confirmed $S$. neurona infection. More importantly, 8 horses negative for $S$. neurona-associated EPM were infected by other unidentified apicomplexans. Of these, 5 tested negative by IBT, but sera from 3 had weak reactivity in the IBT (Daft et al., 2002). It is difficult to interpret the significance of an equivocal result by testing a given horse at a single time point. For clinical specimens, it is recommended that a subsequent specimen (4-8 wk later) be tested and compared with the original result. Whereas some horses may progress to increased immunoreactivity, others may remain weak, probably representing a much earlier exposure to the parasite or, possibly, a very low level of nonspecific reactivity. Marsh et al. (1998) reported $S$. neurona immunoreactivity in a horse diagnosed with encephalitis due to $N$. hughesi. In light of the findings of the studies by Daft et al. (2002) and the present study and from the findings on other naturally infected horses (Dubey, Kerber, and Granstrom, 1999; Dubey, Venturini et al., 1999) and experimentally infected rabbits, there is no evidence that $S$. neurona-specific antibodies detected by IBT react with Neospora spp. antigens. It seems most likely that the horse was exposed to both parasites. The presence of $S$. neuronaspecific antibodies in horses from central Wyoming is puz- 
zling and suggests that another definitive host may be involved or that the parasite shares antigens with another protozoan.

\section{LITERATURE CITED}

Bentz, B. G., D. E. Granstrom, And S. StAmper. 1997. Seroprevalence of antibodies to Sarcocystis neurona in horses residing in a county of southeastern Pennsylvania. Journal of the American Veterinary Medical Association 210: 517-518.

Blythe, L. L., D. E. Granstrom, D. E. Hansen, L. L. Walker, J. BARTLETT, AND S. STAMPER. 1997. Seroprevalence of antibodies to Sarcocystis neurona in horses residing in Oregon. Journal of the American Veterinary Medical Association 210: 525-527.

Cheadle, M. A., D. S. Lindsay, S. Rowe, C. C. Dykstra, M. A. Williams, J. A. Spencer, M. A. Toivio-Kinnucan, S. D. Lenz, J. C. Newton, M. D. Rolsma, and B. L. Blagburn. 1999. Prevalence of antibodies to Neospora sp. in horses from Alabama and characterization of an isolate recovered from a naturally infected horse. International Journal for Parasitology 29: 1537-1543.

Cutler, T. J., R. J. MacKay, P. E. Ginn, E. C. Greiner, R. Porter, C. A. Yowell, AND J. B. Dame. 1999. Are Sarcocystis neurona and Sarcocystis falcatula synonymous? A horse infection challenge. Journal of Parasitology 85: 301-305.

Daft, B. M., B. C. BARR, N. Collins, AND K. Sverlow. 1996. Neospora encephalomyelitis and polyradiculoneuritis in an aged mare with Cushing's disease. Equine Veterinary Journal 28: 240-243.

, I. A. Gardner, D. Read, W. Bell, K. G. Peyser, A. ARdans, H. Kinde, AND J. K. Morrow. 2002. Sensitivity and specificity of Western blot testing of cerebrospinal fluid and serum for diagnosis of equine protozoal myeloencephalitis in horses with and without neurologic abnormalities. Journal of the American Veterinary Medical Association 221: 1007-1013.

Dubey, J. P., And C. P. Beattie. 1988. Toxoplasmosis of animals and man. CRC Press, Boca Raton, Florida, 220 p.

- AND G. DESMONTs. 1987. Serological responses of equids fed Toxoplasma gondii oocysts. Equine Veterinary Journal 19: 337 339.

, AND D. S. LindSAY. 1998. Isolation in immunodeficient mice of Sarcocystis neurona opossum (Didelphis virginiana) faeces, and its differentiation from Sarcocystis falcatula. International Journal for Parasitology 28: 1823-1828.

—, AND M. L. Porterfield. 1990. Neospora caninum (Apicomplexa) in an aborted equine fetus. Journal of Parasitology 76: 732734.

, S. W. Davis, C. A. Speer, D. D. Bowman, A. De Lahunta, D. E. Granstrom, M. J. Topper, A. N. Hamir, J. F. Cummings, And M. M. SuTER. 1991. Sarcocystis neurona n. sp. (Protozoa: Apicomplexa), the etiologic agent of equine protozoal myeloencephalitis. Journal of Parasitology 77: 212-218.

- C. E. Kerber, And D. E. Granstrom. 1999. Serologic prevalence of Sarcocystis neurona, Toxoplasma gondii, and Neospora caninum in horses in Brazil. Journal of the American Veterinary Medical Association 215: 970-972.

- D. S. Lindsay, W. J. A. Saville, S. M. Reed, D. E. GranSTROM, AND C. A. SPEER. 2001. A review of Sarcocystis neurona and equine protozoal myeloencephatitis (EPM). Veterinary Parasitology 95: 89-131.

-, S. Liddell, D. Mattson, C. A. Speer, D. K. Howe, and M. C. Jenkins. 2001. Characterization of the Oregon isolate of Neospora hughesi from a horse. Journal of Parasitology 87: 345-353.

- S. Romand, P. Thulliez, O. C. H. Kwok, S. K. Shen, and H. R. Gamble. 1999. Prevalence of antibodies to Neospora caninum in horses in North America. Journal of Parasitology 85: 968-969. , P. Thulliez, S. Romand, O. C. H. KwoK, S. K. Shen, and H. R. GAmble. 1999. Serologic prevalence of Toxoplasma gondii in horses slaughtered for food in North America. Veterinary Parasitology 86: $235-238$.

, M. C. Venturini, L. Venturini, J. McKinney, and M. PecorARO. 1999. Prevalence of antibodies to Sarcocystis neurona, Toxoplasma gondii, and Neospora caninum in horses from Argentina. Veterinary Parasitology 86: 59-62.
Fenger, C. K., D. E. Granstrom, A. A. Gajadhar, N. M. Williams, S. A. McCrillis, S. Stamper, J. L. Langemeier, and J. P. Dubey. 1997. Experimental induction of equine protozoal myeloencephalitis in horses using Sarcocystis sp. sporocysts from the opossum (Didelphis virginiana). Veterinary Parasitology 68: 199-213.

Granstrom, D. E., J. P. Dubey, S. W. Davis, R. FAYer, J. C. Fox, K. B. Poonacha, R. C. Giles, and P. F. Comer. 1993. Equine protozoal myeloencephalitis: Antigen analysis of cultured Sarcocystis neurona merozoites. Journal of Veterinary Diagnostic Investigation 5: $88-90$.

Gray, M. L., B. G. Harmon, L. Sales, and J. P. Dubey. 1996. Visceral neosporosis in a 10-year-old horse. Journal of Veterinary Diagnostic Investigation 8: 130-133.

Gupta, G. D., J. Lakritz, J. H. Kim, D. Y. Kim, J. K. Kim, and A. E. MARSH. 2002. Seroprevalence of Neospora, Toxoplasma gondii, and Sarcocystis neurona antibodies in horses from Jeju island, South Korea. Veterinary Parasitology 106: 193-201.

Hamir, A. N., S. J. Tornquist, T. C. Gerros, M. J. Topper, And J. P. DubeY. 1998. Neospora caninum-associated equine protozoal myeloencephalitis. Veterinary Parasitology 79: 269-274.

LindSAY, D. S., AND J. P. DuBey. 2001. Direct agglutination test for the detection of antibodies to Sarcocystis neurona in experimentally infected animals. Veterinary Parasitology 95: 179-186.

- , H. Steinberg, R. R. Dubielzig, S. D. Semrad, D. M. Konkle, P. E. Miller, and B. L. Blagburn. 1996. Central nervous system neosporosis in a foal. Journal of Veterinary Diagnostic Investigation 8: 507-510.

Marsh, A. E., B. C. Barr, J. Madigan, J. Lakritz, R. Nordhausen, AND P. A. ConRAD. 1996. Neosporosis as a cause of equine protozoal myeloencephalitis. Journal of the American Veterinary Medical Association 209: 1907-1913.

$\longrightarrow,-$ A. E. Packham, AND P. A. ConRad. 1998. Description of a new Neospora species (Protozoa: Apicomplexa: Sarcocystidae). Journal of Parasitology 84: 983-991.

McAllister, M. M., J. P. Dubey, D. S. Lindsay, W. R. Jolley, R. A. Wills, AND A. M. McGuire. 1998. Dogs are definitive hosts of Neospora caninum. International Journal for Parasitology 28: 1473-1478.

Pitel, P.-H., S. Pronost, G. Gargala, D. Anrioud, M.-P. Toquet, N. Foucher, C. Collobert-Laugier, G. Fortier, and J.-J. Ballet, 2002. Detection of Sarcocystis neurona antibodies in French horses with neurological signs. International Journal for Parasitology 32: 481-485.

- , S. Romand, P. Thulliez, G. Fortier, And J. J. BAllet. 2001. Prevalence of antibodies to Neospora caninum in horses in France. Equine Veterinary Journal 33: 205-207.

Pronost, S., P. H. Pitel, S. Romand, P. Thulliez, C. Collobert, and G. FORTIER. 1999. Neospora caninum: Premiére mise en évidence in France sur un avorton équin, analyse et perspectives. Pratique Véterinaire Equine 31: 31-34.

Romand, S., P. Thulliez, AND J. P. Dubey. 1998. Direct agglutination test for serologic diagnosis of Neospora caninum infection. Parasitology Research 84: 50-53.

Rossano, M. G., J. B. Kaneene, J. V. Marteniuk, B. D. Banks, H. C. SchotT, AND L. S. MANSFIELD. 2001. The seroprevalence of antibodies to Sarcocystis neurona in Michigan equids. Preventive Veterinary Medicine 48: 113-128.

—, L. S. Mansfield, J. B. Kaneene, A. J. Murphy, C. M Brown, H. C. Sснот,, and J. C. Fox. 2000. Improvement of Western blot test specificity for detecting equine serum antibodies to Sarcocystis neurona. Journal of Veterinary Diagnostic Investigation 12: 28-32.

Saville, W. J., S. M. Reed, D. E. Granstrom, K. W. Hinchcliff, C. W. Kohn, T. E. WitTum, AND S. Stamper. 1997. Seroprevalence of antibodies to Sarcocystis neurona in horses residing in Ohio. Journal of the American Veterinary Medical Association 210: 519-524. , R. W. Stich, S. M. Reed, C. J. Nuoku, M. J. Oglesbee, A. Wunschmann, D. L. Grover, A. L. Larew-Naugle, J. F. Stanek, D. E. Granstrom, and J. P. Dubey. 2001. Utilization of stress in the development of an equine model for equine protozoal myeloencephalitis. Veterinary Parasitology 95: 211-222.

Sofaly, C. D., S. M. Reed, J. C. Gordon, J. P. Dubey, M. J. Oglesbee, C. J. NJoku, D. L. Grover, AND W. J. A. Saville. 2002. Experi- 
mental induction of equine protozoal myeloencephalitis (EPM) in the horse: Effect of Sarcocystis neurona sporocyst inoculation dose on the development of clinical neurologic disease. Journal of Parasitology 88: 1164-1170.

Tillotson, K., P. M. McCue, D. E. Granstrom, D. A. Dargatz, M. O. Smith, and J. L. Traub-Dargatz. 1999. Seroprevalence of an- tibodies to Sarcocystis neurona in horses residing in northern Colorado. Journal of Equine Veterinary Science 19: 122-126.

Vardeleon, D., A. E. Marsh, J. G. Thorne, W. Loch, R. Young, and P. J. Johnson. 2001. Prevalence of Neospora hughesi and Sarcocystis neurona antibodies in horses from various geographical locations. Veterinary Parasitology 95: 273-282. 